Jurnal Akuakultur Sungai dan Danau Vol. 2 No. 2 Tahun 2017 Hal. 58 - 64

ISSN Print 2503-4766

ISSN Online 2597-8837

\title{
PENGARUH TUMBUHAN AZOLLA (Azolla microphylla) TERHADAP KELANGSUNGAN HIDUP IKAN PATIN (Pangasianodon hypophthalmus)
}

\author{
Yustika Anggraini ${ }^{1}$, Syahrizal ${ }^{1}$, M. Yusuf Arifin ${ }^{1}$ \\ Program Studi Budidaya Perairan, Fakultas Pertanian, Universitas Batanghari \\ Jalan Slamet Riyadi, Broni, Jambi 3612236122, Telp. +62074160103 \\ *email korespondensi: syahrizal.syukur@yahoo.com
}

\begin{abstract}
Abstrack
Azolla (Azolla microphylla) aquatic plants can be used as a natural feed or as a source of artificial feed ingredients (pellets) of fish. In addition to Azolla plant as a fish feed, Azolla plant grown in fish maintenance water media can help improve water quality, because it can function as phytoremediation. The aim of this research is to see the influence of Azolla (Azolla microphylla) plant to survival rate on siamese catfish (Pangasianodon hypophthalmus) fish. The method used in this research is complete randomized design with 4 treatments and 3 replications. Treatment A. Without Azolla microphylla (control), B.Azolla microphylla treatment of $150 \mathrm{~g} / \mathrm{m} 2$, Treatment $C$. Azolla. microphylla as much as 250 grams / m2, and D.Azolla microphylla as much as 350 grams / $m 2$. The survival of the best catfish P1 54,20\%, consecutive P2 28,30, P3 26,70 and $P 0$ 22,50. Initial ammonia concentration $0.33 \mathrm{mg} / \mathrm{l}$ after experiments $P 0$ 0.34, P1 0.27, P2 0.27 and P3 0.24 with correction factors P1 0.443, P2 435 and P3 0.541. The association of Azolla count toward survival of fish gave no significant correlation to survival $R=0.017$, whereas the relation of the amount of azolla to ammonia correlated significantly $R=0.903$. The best density of Azolla $350 \mathrm{gram} / \mathrm{m} 2$ plant on water surface media that can function as phytoremediation to absorb the remnants of fish and fish waste, so as to improve the water quality factor and at the same time can increase the growth of Siamese (Pangasianodon hypophthalmus) fish biomass and affect the production of Azolla biomass.
\end{abstract}

Keywords: phytoremediation, azolla, catfish

\begin{abstract}
Abstrak
Tumbuhan air Azolla (Azolla microphylla) dapat dijadikan pakan alami atau sebagai salah satu sumber bahan pakan buatan (pellet) ikan. Selain tumbuhan Azolla sebagai pakan ikan, Azolla yang ditanam dalam media air pemeliharaan ikan dapat membantu memperbaiki kualitas air, karena dapat berfungsi sebagai fitoremediasi. Penelitian yang dilakukan bertujuan melihat efektifitas tumbuhan Azolla (Azolla microphylla) sebagai fitoremediasi pada media pemeliharaan ikan patin siam (Pangasianodon hypophthalmus) Tanpa ganti air. Metoda yang digunakan dalam penelitian ini adalah rancangan acak lengkap (RAL) dengan 4 perlakuan dan 3 ulangan. Perlakuan A. Tanpa Azolla microphylla (kontrol), Perlakuan B.Azolla microphylla sebanyak $150 \mathrm{gram} / \mathrm{m}^{2}$, Perlakuan C. Azolla. microphylla sebanyak $250 \mathrm{gram} / \mathrm{m}^{2}$, dan D. Azolla microphylla sebanyak $350 \mathrm{gram} / \mathrm{m}^{2}$. Kelangsungan hidup ikan patin terbaik P1 54,20\%, berturutturut P2 28,30, P3 26,70 dan P0 22,50. Konsentrasi amonia awal $0.33 \mathrm{mg} / \mathrm{l}$ setelah percobaan P0 0,34, P1 0,27, P2 0,27 dan P3 0,24 dengan Faktor Koreksi P1 0,443, P2 435 dan P3 0,541. Hubungan jumlah Azolla terhadap kelangsungan hidup ikan memberikan korelasi tidak nyata bagi kelangsungan hidup $\mathrm{R}=0,017$, sedangkan hubungan jumlah azolla terhadap ammonia berkorelasi secara nyata $\mathrm{R}=0,903$.
\end{abstract}


Jurnal Akuakultur Sungai dan Danau Vol. 2 No. 2 Tahun 2017 Hal. 58 - 64

ISSN Print 2503-4766

ISSN Online 2597-8837

Kepadatan tanaman Azolla 350 gram $/ \mathrm{m}^{2}$ terbaik pada permukaan air media yang dapat berfungsi sebagai fitoremediasi menyerap sisa pakan dan kotoran ikan, sehingga dapat memperbaiki faktor kualitas air dan sekaligus dapat meningkat pertumbuhan biomassa ikan patin siam dan mempengaruhi produksi biomass Azolla.

Kata Kunci: Fitoremediasi, azolla, ikan patin

\section{PENDAHULUAN}

Ikan patin siam (Pangasianodon hypophthalmus) adalah salah satu ikan air tawar yang sangat digemari masyarakat hal ini disebabkan oleh daging ikan punya nilai gizi protein dan lemak yang baik untuk kesehatan dan daging ikan patin dikenal punya rasa yang enak dan gurih. Bagi pembudidaya ikan patin disukai, karena ikan patin memiliki karakteristik pertumbuhan yang cepat sehingga dapat menhasilkan produksi yang tinggi, kemudian diikuti harga jual ikan patin relatif baik dan menguntungkan. Ikan patin ini dibudidayakan diprovinsi Jambi dilakukan dalam kolam dan lebih banyak dalam keramba jaring apung yang dipelihara di danau dan sungai yang utama pada Sungai Batanghari.

Faktor penyebab keberhasilan dan kegagalan petani budidaya ikan patin diantaranya adalah faktor kualitas benih, mutu pakan dan lingkungan. Bila faktor benih dan pakan sudah optimal, maka faktor pengendalian lingkungan sangat penting, karena faktor lingkungan merupakan dapat berfungsi sebagai limiting faktor (faktor pembatas). Keberadaan tumbuhan Azolla didalam perairan dapat berfungsi sebagai pengendali limiting faktor.

Banyak kreasi, rekayasa dan manfaat bila ada kombinasi pemeliharaan tanaman azolla dengan budidaya ikan patin siam. Menurut Stepniewska, 2005 bahwa tumbuhan Azolla mampu tumbuh cepat dengan biomassa besar dan mampu menyerap beberapa jenis logam berat sehingga berpotensi sebagai fitoabsorber limbah yang mengandung logam berat. Tanaman azolla bisa berfungsi fitoremediasi yang dapat meyerap sisa pakan, feses dan polutan. Bahan organik dari sisa pakan dan fises dibangun terutama oleh karbon dan hidrogen, dan dapat mengandung unsur-unsur lain seperti nitrogen, oksigen, fosfor, halogen dan belerang, unsur ini di dekomposisi diperairan menjadi unsur anorganik berupa unsur hara yang diperlukan sebagai nutrisi untuk perkembangan tumbuhan Azolla bila ada cahaya Matahari. Organisme pengurai perentara seperti bakteri dan jamur memanfaatkan sebagian hasil bahan organik melepaskan bahan-bahan sederhana yang dapat digunakan kembali oleh produsen Azolla. Pada ekosistem perairan komponen biotik yang berperan adalah tumbuhan hijau sebagai produser, bermacam-macam kelompok hewan sebagai konsumer, dan bakteri serta fungi sebagai dekomposer.

Tanaman air belum menjadi pola pemeliharaan bagi petani ikan di Indonesia sebagai prasarana perbaikan kualitas air untuk budidaya ikan. Tumbuhan Azolla diduga akan dapat memperbaiki ekosistem kolam tidak mengalir atau air yang tidak bertukar (lentik) seperti ekosistem perairan, kolam tadah hujan, danau atau rawa. Berdasarkan masalah diatas, perlu kiranya dilakukan penelitian tentang pengaruh tumbuhan Azolla (Azolla microphylla) terhadap kelangsungan hidup ikan patin siam.

\section{METODOLOGI PENELITIAN}

Penelitian ini dilaksanakan pada bulan Februari 2017 selama 1 (satu) bulan. Tempat pelaksanaan penelitian di Laboratorium Basah Fakultas Pertanian Universitas Batanghari Jambi, dengan kondisi lingkungan semi terbuka. Rancangan lingkungan 
Jurnal Akuakultur Sungai dan Danau Vol. 2 No. 2 Tahun 2017 Hal. 58 - 64

yang digunakan adalah rancangan acak lengkap (RAL) 4 perlakuan, masing-masing perlakuan diulang sebanyak 3 kali. Model percobaan yang digunakan dalam penelitian ini adalah model linier dengan massa perbandingan tanaman A. microphylla masingmasing akuarium perlakuan A : Tanpa A. microphylla (kontrol), perlakuan B : Dengan A. microphylla sebanyak 150 gram $/ \mathrm{m}^{2}$, C. A. microphylla sebanyak $250 \mathrm{gram} / \mathrm{m}^{2}$, dan D A. microphylla sebanyak $350 \mathrm{gram} / \mathrm{m}^{2}$. Data yang diperoleh dianalisis statistik menggunakan program SPSS, yaitu data yang diuji berupa perbedaan antar kelompok dengan Anova dilanjut dengan BNT dan hubungan antara variabel bebas (independen) dengan variabel terikat (dependen), untuk melihat hubungan antar variabel diperlukan digunakan uji korelasi dan regresinya.

Ikan uji yang digunakan adalah benih ikan patin ukuran $5-7 \mathrm{~cm}$ sebanyak 5 ekor/L, padat tebar masing-masing sebanyak 100 ekor/akuarium, sehingga benih yang digunakan yaitu 1.200 ekor. Benih ikan ini terlebih dahulu diaklimatisasi dan diberi pakan buatan selama 3 hari. Azolla yang digunakan adalah A. microphylla yang berasal dari Instalasi Ikan Hias Milik Dinas Kelautan dan Perikanan Provinsi Jambi. Wadah yang digunakan berupa akuarium sebanyak 12 unit dengan ukuran 50 x $100 \times 50 \mathrm{~cm}$ dengan volume air 20 liter yang disusun secara acak. Masing-masing akuarium dilengkapi aerasi sebagai oksigen tambahan.

Setelah ikan uji dimasukkan kedalam masing-masing akuarium yang telah disusun secara acak yang diberikan azolla sesuai dengan perlakuan kecuali pada akuarium kontrol. Pakan yang diberikan berupa pakan buatan dengan frekuensi pemberian pakan adalah $3 \mathrm{kali} / \mathrm{hari}$ yaitu setiap pukul 09.00, 14.00 dan 18.00 WIB dengan at satiation (diberi makan sampai kenyang). Untuk melihat efektifitas azolla maka selama pemeliharaan benih tidak dilakukan pergantian air.

Parameter yang diamati berupa tingkat kelangsungan hidup dihitung dengan menggunakan rumus sebagai berikut (Effendi, 2003) :

$$
S R=\frac{N t}{N 0} \times 100 \%
$$

Keterangan :

$\mathrm{SR}=$ Kelangsungan hidup/Survival Rate (sintasan)

$\mathrm{Nt}=$ Jumlah ikan diakhir penelitian

No $=$ Jumlah ikan diawal penelitian

Perhitungan kadar ammonia air dan azzola dalam media pemeliharaan ikan patin percobaan menggunakan metode spektrofotometri dilaboratorium. Parameter kualitas air yang diamati dan metode pelaksanaan faktor fisika dan kimia sebagai mana pada tabel 1 berikut ini :

Tabel. 1. Metode pengukuran parameter kualitas air (fisika dan kimia air) percobaan

\begin{tabular}{lll}
\hline Parameter & Satuan & Metode \\
\hline Suhu & ${ }^{0} \mathrm{C}$ & Pembacaan skala \\
pH & Unit & Pembacaan skala \\
Oksigen terlarut & $\mathrm{mg} / \mathrm{L}$ & Titrimetri \\
Karbondioksida & $\mathrm{mg} / \mathrm{L}$ & Titrimetri \\
Ammonia & $\mathrm{mg} / \mathrm{L} \mathrm{CaCO}$ & Spektrofotometri \\
Nitrit & $\mathrm{mg} / \mathrm{L} \mathrm{CaCO}_{3}$ & Spektrofotometri \\
Nitrat & $\mathrm{mg} / \mathrm{L} \mathrm{CaCO}$ & Spektrofotometri \\
\hline
\end{tabular}




\section{HASIL DAN PEMBAHASAN}

Hasil pengamatan untuk mengetahui pengaruh tumbuhan Azolla (Azolla microphylla) terhadap kelangsungan hidup ikan patin siam (Pangasianodon hypophthalmus) berupa pengaruh dan hubungan perbedaan jumlah tumbuhan Azolla dalam wadah pemeliharaan terhadap $\mathrm{NH}_{3}$ dan kelangsungan hidup benih ikan patin tanpa ganti air selama penelitian adalah tingkat kelangsungan hidup ikan percobaan rata-rata berkisar 22,50\% - 54,20\%. Ammonia sebagai indikasi kualitas air diperoleh $0,16 \mathrm{mg} / \mathrm{L}-0,35 \mathrm{mg} / \mathrm{L}$ dimana pada awal penelitian $0,33 \mathrm{mg} / \mathrm{L}$. Untuk melihat pengaruh dan hubungan berbagai variabel di atas akan dianalisis sebagai berikut ini:

\section{Pengaruh dan Hubungan Azolla Terhadap Kelangsungan Hidup Patin}

Hasil pengamatan terhadap hubungan jumlah azolla terhadap kelangsungan hidup, selama masa pemeliharaan dapat dilihat dari tabel 3 sebagai berikut :

Tabel 3. Rata-rata Biomass Azolla (A. microphylla) dan Kelangsungan Hidup Patin Patin (P. hypophthalmus) Percobaan

\begin{tabular}{cccc}
\hline Perlakuan & Biomass Azolla (gram) & SR $(\%)$ & Notasi \\
\hline P0 & 0,00 & 22,50 & $\mathrm{a}$ \\
P1 & 18,5 & 54,20 & $\mathrm{a}$ \\
P2 & 41,4 & 28,30 & $\mathrm{ab}$ \\
P3 & 54,23 & 26,70 & $\mathrm{ab}$ \\
\hline
\end{tabular}

\section{SR = Sulvivar Rate (Kelangsungan Hidup)}

Kelangsungan hidup ikan patin antar perlakuan pada tabel 3 menunjukan pengaru nyata $(\mathrm{P}<0,5)$ perbedaan tersebut pada $\mathrm{P} 0$ dan $\mathrm{P} 1$ dengan $\mathrm{P} 2$ dan $\mathrm{P} 3$. Terjadinya perbedaan SR yang signifikan diduga disebabkan P0 dan $\mathrm{P} 1$ kualitas air yang buruk terutama usur amoniak (NH3) dan $\mathrm{CO}_{2}$ tinggi, sebaliknya $\mathrm{O}_{2}$ rendah dengan $\mathrm{P} 2$ dan $\mathrm{P} 3$ punya kualitas air yang baik (lampiran 7 dan 8). Hal ini disebabkan tidak adanya tanaman azolla (A. microphylla) P0dan P1, sehingga kadar ammonia yang tidak terionisasi dan tidak terserap oleh tanaman. Ammonia dan $\mathrm{CO}_{2}$ yang terlalu tinggi dapat menyebabkan rusaknya sistem pernapasan dan toksik bagi ikan, dengan demikian tingkat kelangsungan hidup pada P0 dan P1 lebih rendah. Menurut Juswardi et.,al, (2010) bahwa semakin besar kadar ammonia yang terkandung dalam air maka akan semakin kecil pertambahan berat segar dan kecepatan pertumbuhan $N$. oletacea. Semakin banyak tanaman yang mati sehingga sumber ammonia bertambah akibat pemecahan nitrogen organik dari tanaman tersebut. Berdasarkan hasil penelitian Sitompul et.,al, (2012) menunjukkan hasil yang sama yaitu pada perlakuan A (tanpa Azolla sp) kelangsungan hidup ikan terendah sebesar 24,99\% dibanding perlakuan lain dengan pemberian Azolla sp SR sebesar 81,94\% - 93,04\%.

Grafik hubungan tanaman Azolla terhadap kelangsungan hidup benih ikan patin dapat dilihat pada grafik gambar 3 . 
Jurnal Akuakultur Sungai dan Danau Vol. 2 No. 2 Tahun 2017 Hal. 58 - 64

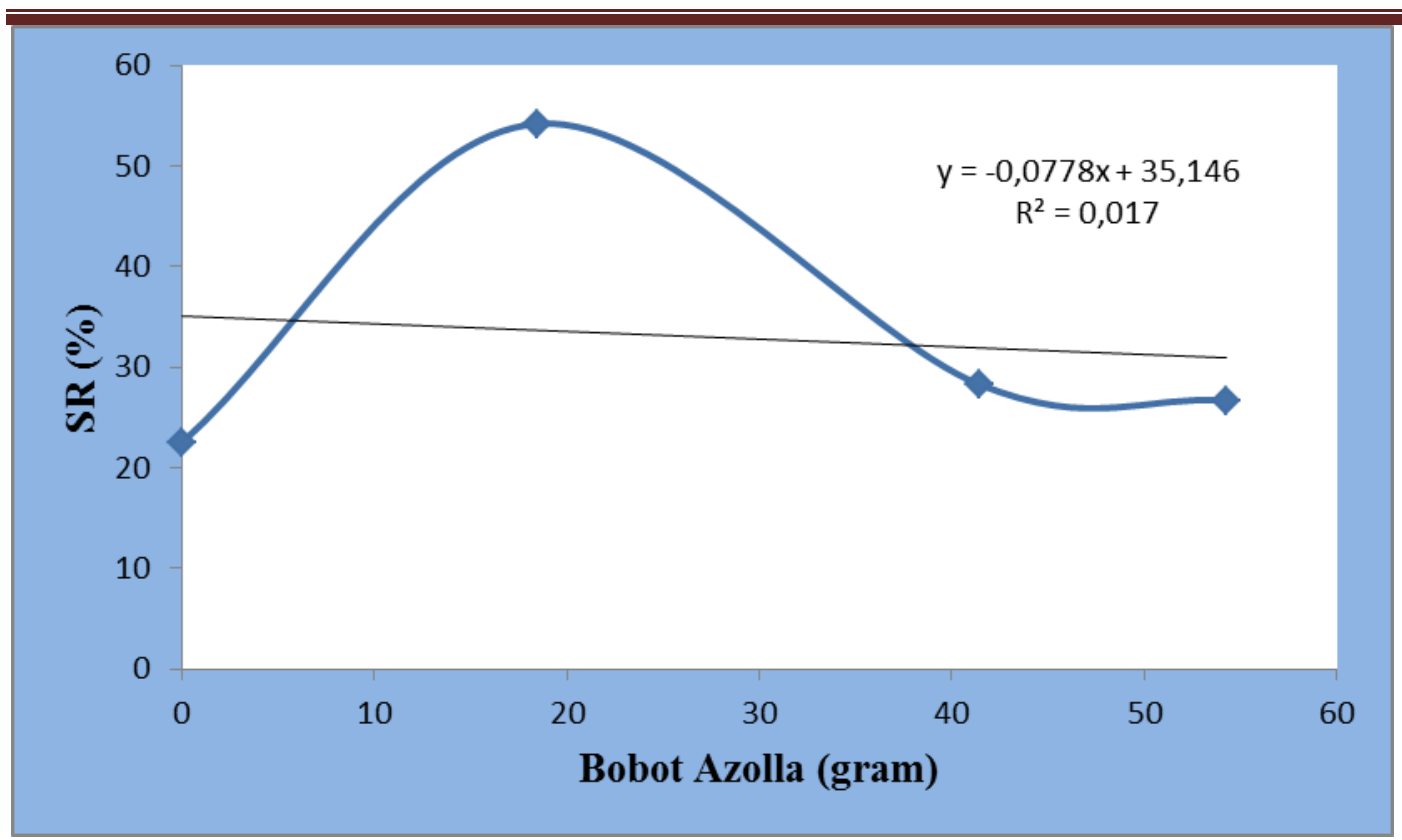

Gambar 3. Grafik hubungan bobot azolla terhadap kelangsungan hidup patin

Berdasarkan data dan grafik gambar 3 menunjukkan bahwa semakin banyak kadar ammonia maka tingkat kelangsungan hidup semakin menurun ditunjukan oleh analisis regresi $\mathrm{R}^{2}=0,017$ daan $\mathrm{Y}=-0,00778 \mathrm{x}+35,146$. Keeratan hubungan diperkirakan disebabkan ada peran jumlah azolla mempengaruhi perbaikan kualitas air, sehingga dapat dilihat tingkat kematian tinggi. Apabila keadaan fisika kimia air tidak sesuai dengan kebutuhan, maka akan terjadi gangguan pada proses fisiologi yang terjadi dan mempengaruhi kelangsungan hidup dan pertumbuhan. Parameter fisika air meliputi suhu, kecerahan. Kimia air meliputi oksigen, ammonia, kesadahan, pH dan salinitas (Effendi, 2003). Menurut Reebs (2009), ikan yang nenperoleh oksigen rendah akan mudah mengalami stress hingga akhirnya terjadi kematian. Pada penelitian ini kematian tertinggi terjadi pada perlakuan P0 tanpa azolla (kontrol) dengan kadar oksigen berkisar antara 3,47 $\mathrm{mg} / \mathrm{L}-4,20 \mathrm{mg} / \mathrm{L}$ dengan rata-rata kadar ammonia tertinggi yaitu $0,34 \mathrm{mg} / \mathrm{L}$. Semakin tinggi konsentrasi toksikan organik dalam perairan maka semakin rendah kandungan oksigen terlarut dan semakin tinggi kadar ammonia (Effendi, 2003). Meningkatnya konsentrasi ammonia melebihi ambang batasn menyebabkan lapisan epitel pada filamen insang tidak berfungsi melakukan difusi oksigen, sehingga hemoglobin dalam darah tidak cukup membawa oksigen ke seluruh tubuh. Hal ini mengakibatkan sistem metabolisme terganggu dan ikan terlihat lemas serta berkumpul di saluran aerasi untuk mendapatkan oksigen. Kandungan oksigen terlarut (DO) minimum adalah 2 ppm dalam keadaan normal dan tidak tercemar oleh senyawa beracun (toksik). Kandungan oksigen minimum ini sudah cukup mendukung kehidupan organisme (Swingle, 1968).

\section{Parameter Kualitas Air}

Berdasarkan hasil penelitian kisaran suhu berada pada $25,8^{0} \mathrm{C}-28,3^{0} \mathrm{C}$. Menurut Effendie (2003), perubahan suhu melebihi $3-4{ }^{0} \mathrm{C}$ akan menyebabkan perubahan metabolisme yang mengakibatkan kejutan suhu, meningkatkan toksisitas kontaminan yang terlarut, menurunkan DO dan meningkatkan kematian pada ikan. Kisaran suhu optimal bagi kehidupan ikan adalah $25^{\circ} \mathrm{C}-30^{\circ} \mathrm{C}$. 
Jurnal Akuakultur Sungai dan Danau Vol. 2 No. 2 Tahun 2017 Hal. 58 - 64

ISSN Print 2503-4766

ISSN Online 2597-8837

Selama penelitian $\mathrm{pH}$ air di wadah pemeliharaan berkisar antara 5,73-6,89. Kesuburan perairan dipengaruhi oleh $\mathrm{pH}$ karena mempengaruhi kehidupan jasad renik. Perairan asam akan kurang produktif, bahkan dapat membunuh hewan budidaya. Pada $\mathrm{pH}$ rendah, kandungan DO akan berkurang, sebagai akibatnya konsumsi oksigen menurun, aktivitas naik dan selera makan berkurang. Hal ini sebaliknya terjadi pada suasana basa. Menurut Boyd (1982) $\mathrm{pH}$ yang optimal untuk pertumbuhan sebagian besar spesies ikan berkisar antara 6-5 - 9,0.

Nilai DO selama pemeliharaan berkisar antara 3,4 - 4,2 mg/L. Menurut Djariah (2001), kandungan DO yang cukup baik untuk kehidupan ikan patin berkisar $2-5$ $\mathrm{mg} / \mathrm{L}$. Fluktuasi kadar oksigen yang tinggi di perairan hingga mencapai kadar yang sangat rendah berbahaya bagi organisme akuatik.

Kandungan karbondioksida dalam media pemeliharaan selama penelitian berkisar antara $0,30 \mathrm{mg} / \mathrm{L}-1,58 \mathrm{mg} / \mathrm{L}$. Kandungan karbondioksida dalam air untuk pemeliharaan ikan patin sebaiknya kurang dari $5 \mathrm{mg} / \mathrm{L}$. Meskipun perananan $\mathrm{CO}_{2}$ sangat besar bagi organisme akuatik, namun kandungan yang berlebihan sangat mengganggu, bahkan menjadi racun secara langsung bagi biota.

Kadar amonia selama penelitian berkisar antara $0,16 \mathrm{mg} / \mathrm{L}-0,35 \mathrm{mg} / \mathrm{L}$. Kadar amonia tersebut tergolong tinggi, hal ini diduga meningkatnya bahan buangan metabolisme oleh ikan dan kematian azolla yang menjadi amonia juga. Menurut Budiman (2010), konsentrasi ammonia yang ideal bagi ikan tidak lebih dari $1 \mathrm{mg} / \mathrm{L}$. Ikan tidak dapat bertoleransi terhadap kadar amonia bebas yang terlalu tinggi karena dapat menggangu proses pengikatan oksigen oleh darah (Effendie, 2003).

Kandungan nitrit selama pemeliharaan berkisar antara $0,03 \mathrm{mg} / \mathrm{L}-0,21 \mathrm{mg} / \mathrm{L}$. Nurussalam dalam Juhairi (2016) mengatakan konsentrasi nitrit sebesar 0,1 - 0,4 mg/L masih dapat ditolerir oleh ikan-ikan budidaya air tawar. Keberadaan nitrit menggambarkan berlangsungnya proses biologis perombakan bahan organik yang memiliki kadar oksigen terlarut sangat rendah (Effendi, 2003). Nilai nitrit menunjukkan peningkatan selama masa pemelihaan. Hal ini diduga kandungan bahan organik yang terdapat dalam media pemeliharaan tidak tereduksi sempurna dalam proses nitrifikasi menjadi nitrogen, kekurangan bakteri dan oksigen menjadi penyebab utamanya. Nitrat adalah bentuk utama nitrogen alami dan merupakan nutrien utama bagi pertumbuhan tanaman dan alga. Senyawa ini dihasilkan dari proses oksidasi yang sempurna di perairan. Nitrat sangat mudah larut dalam air dan bersifat stabil (Effendie, 2003). Kisaran konsentrasi nitrat selama pemeliharaan yaitu antara $0,01 \mathrm{mg} / \mathrm{L}-0,50 \mathrm{mg} / \mathrm{L}$.

\section{KESIMPULAN}

Berdasarkan penelitian yang dilakukan berupa pemberian A. microphylla memberikan pengaruh dan berhubungan terhadap kualitas air dan dapat dijadikan sebagai fitoremediasi, kesimpulan hasil sebagai berikut :

1. Pemberian tanaman azolla dengan jumlah $150 \mathrm{gram} / \mathrm{m}^{2}$ merupakan perlakuan terbaik untuk kelangsungan hidup ikan patin $(54,17 \%)$.

2. Tanaman azolla dengan jumlah 350 gram $/ \mathrm{m}^{2}$ merupakan penyerapan amonia terbaik dengan kadar ammonia sebesar $0,24 \mathrm{mg} / \mathrm{L}$ diakhir penelitian

3. Hubungan jumlah azolla terhadap kelangsungan hidup benih ikan memberikan korelasi tidak nyata, angka $\mathrm{R}=0,073$ dan $\mathrm{R}=0,017$, sedangkan hubungan jumlah azolla terhadap ammonia memberikan korelasi secara nyata, angka $\mathrm{R}=$ 0,903 . 


\section{DAFTAR PUSTAKA}

Budiman, 2010. Budidaya Ikan Air Tawar Dengan Sistem Keramba Jaring Apung (KJA). Sumatera Selatan.

Boyd CE. 1982. Water Quality Management for Pond Fish Culture. Elsevier Publishing Company. New. Yor 318 p.

Boyd. 1992. Water Quality Management For Pond Fish Culture. Birmingham Publshing Co. Alabama.

Caroline, J dan Moa, G.A. 2015. Fitoremediasi Logam Timbal (Pb) Menggunakan Tanaman Melati Air (Echionodorus palaefolius) Pada Limbah Industri Peleburan Tembaga Dan Kuningan. Jurusan Teknik Lingkungan. Institut Teknologi Adhi Tama Surabaya. Seminar Nasional Sains dan Teknologi Terapan III.

Dewantoro, G.W. 2001. Fekunditas dan Produksi Larva Ikan Cupang (betta spelendens Regan) yang berbeda umur dan pakan alaminya. Fakultas biologi, Universitas Nasional Jakarta. Jurnal Ikhtiologi Indonesia, 1.(2):49-52.

Djariah, A.S. 2001. Budi Daya Ikan Patin. Kanisius. Yogyakarta. 87 hal.

Effendi, H., 2003. Telaah Kualitas Air Bagi Pengelolaan sumber Daya dan Lingkungan Perairan. Penerbit Kanisius. Yogyakarta.

Effendi. 2007. Kimia Koordinasi Jilid I. Malang : Jurusan Kimia Fakultas Matematika dan Ilmu Pengetahuan Alam. Universitas Negeri Malang.

Ernawan, Danang. 2010. Pengaruh Penggenangan Dan Konsentrasi Timbal $(\mathrm{Pb})$ Terhadap Pertumbuhan Dan Serapan Pb Azolla Microphylla Pada Tanah Berkarakter Kimia Berbeda. Skripsi. Surakarta : Universitas Sebelas Maret.

Juhairi, Ahmad. 2016. Toksisitas dan Akumulasi Kadmium (Cd) Terhadap Tingkat Kematian dan Kerusakan Organ Ikan Nila (Orechromis niloticus L) : [Skripsi]. Program studi Budidaya Perairan Fakultas Pertanian, Jambi : Universitas Batanghari.

Juswardi, Efendi S, Lilian F. 2010. Pertumbuhan Neptunia oleracea Lour Pada Limbah Cair Ammoniak Dari Industri Pupuk Urea Sebagai Upaya Pengembangan Fitoremediasi. Jurnal Penelitian Sains. 13(1) : 17-20.

Muhtadin. 2012. Pengaruh Penambahan Azolla microphylla terhadap Penurunan Kadar COD dan Fosfat pada Variasi Konsentrasi Limbah Cair Laundry "Bg" Di Kelurahan Warungboto Kecamatan Umbulharjo Yogyakarta. Skripsi. Yogyakarta : Universitas Ahmad Dahlan.

Reebs, S.G. 2009. Oxygen and Fish Behavior. Universite de Moncton. Canada.

Stepniewska, Z. 2005. Potential of Azolla Caroliniana for The Removal of Pb and $\mathrm{Cd}$ from Wastewaters. International Agrophysics ISSN 0236-8722 CODEN INAGEX 2005, vol. 19, $\mathrm{n}^{0} 3$, pp. 251-255 [5 page (s) (article)] (25 ref.)

Suarsana, M. 2011. Habitat dan Niche Paku Air Tawar (Azolla pinata Linn.) (Suatu kajian Komponen Penyusun Ekosistem). Vol. 11, No. 2. Fakultas pertanian UNIPAS Singaraja. Medan.

Swingle, H. S. 1968. Standarization of Chemical Analysis for Water and Pond Muds. FAO Fish rep., Vol 3.

Yosmaniar. 2009. Toksisitas Niklosamida Terhadap pertumbuhan Kondisi Hematologi dan Histopatologi Juvenil Ikan Mas (Crypinus carpio). Tesis. Sekolah Pasca Sarjana. IPB. Bogor. 